\title{
The Intersection between UCC Article 9 and Intellectual Property: The Need for a National, Centralized Filing System for IP \\ Willa E Gibson*
}

Dean's Club Professor of Law, The University of Akron School of Law, Akron, USA

Keywords: Intellectual property; State UCC Law; Federal Law; Copy rights; Patents

\section{Introduction}

Intellectual property has emerged as a commercially valuable, dominant asset in our economy [1] that has become a necessary component to stimulating and promoting our "free-enterprise, marketbased system [2]." Intellectual property is employed in all sectors of the economy, and in practically all U.S. industries, the assertion of intellectual property rights have become the basis for protecting creative and innovative ideas. The use of patents, trademarks, and copyrights evidencing ownership of innovative ideas provides a legal means to promote economic benefits to businesses, their employees, and consumers [2]. Overall, "IP -intensive industries accounted for about $\$ 5.06$ trillion in value added, or 34.8 percent of U.S. gross domestic product (GDP), in 2010 [2]. Further, the use of intellectual property as collateral to secure financing also stimulates and promotes economic growth [3]. Financing transactions secured by intellectual property provide a boon to both debtors and creditors. Such financing provides an additional means for businesses to obtain capital infusions while providing creditors with additional loan assets and interest income. Despite the economic benefits derived from securitizing intellectual property, such financing present questions of federalism primarily related to whether a lender must record its security interests in intellectual property with a state or federal recordation system to provide appropriate notice to prevail against competing interests. The Supremacy Clause of the Constitution provides that federal law is "the supreme law of the land [4]. Accordingly, state laws in conflict with federal laws are invalid [5]. Hence, the preemption doctrine derived from the Supremacy Clause of the Constitution provides that federal laws can expressly or impliedly preempt state laws that conflict with them.

However, the jurisprudence addressing whether the Copyright, Patent, and Lanham Acts-the statutes providing for recordation of interests in copyrights, patents, and trademarks respectively-preempt state UCC recording requirements is comprised of a patchwork of opinions without any definitive guidance on which lenders feel they can predictably rely. On a federal level, the Copyright, Patent, and Lanham Acts all include priority provisions that require parties with certain interests in copyrights, patents, and trademarks respectively, to record those interests within a specified time frame in the statute's designated federal office to prevail against competing interests [6-8]. On a state level, the securitization of personal property including intellectual property is generally governed by each state's versions of Uniform Commercial Code (UCC) of Article 9, which typically requires lenders to record their security interests by filing a financing statement with the appropriate state [9]. The federalism question is whether the priority provisions in the Copyright, Patent, or Lanham Act preempt the UCC filing system, thus requiring lenders with security interests in copyrights, patents, or trademarks respectively to record their interests with the federal office designated by the federal statute to secure priority over competing interests. Since the patchwork of legal opinions interpreting whether those federal statutes preempt state UCC filing requirements creates unease amongst lenders, lenders have resorted to dual filingsrecording their security interests with both the federal office designated by the applicable federal statute and with the state designated by the UCC-to best protect their security interests [10]. Moreover, the lack of definitive legal guidance most likely restricts intellectual property secured financing, a source of capital that businesses could employ to spur investment and innovation, both of which support and stimulate our economy. To eliminate the uncertainty that most likely stymies secured financing in assets that have emerged as immensely valuable to economic growth, Congress should enact federal legislation that creates a centralized, national, online filing system. Intellectual property rights are dominant assets on the financial statement of many businesses [11]. Consistent with the tremendous growth in the intellectual property industry, the law should provide lenders with a centralized filing system that brings predictability to securitization of intellectual property. Such a system would most likely increase secured financing in intellectual property inuring not only to benefit of creditors and their borrowers, but also to the economy.

\section{State UCC Law and Intellectual Property}

Article 9 of the UCC provides that effective collateralization of personal property requires a lender to attach and to perfect its security interest in that property [12]. Federal statutes regulating intellectual property law do not preempt the attachment requirements of Article 9 [13]. Generally, lenders satisfy the attachment requirements by executing a security agreement authenticated by the debtor that describes the intellectual property, which UCC classifies as "general intangibles" [12]. The UCC perfection laws require that lenders provide notice of their security interests to third parties, and a filing a financing statement with the appropriate state is a common means by which lenders can satisfy the notice-perfection requirements for most type of personal property including intellectual property [9]. UCC state laws provide that the timing of the filing may, in certain instances, serve to rank the lenders priority in relation to subsequent competing parties since the financing statement filing provides constructive notice [14].

\section{Federal Law and Intellectual Property}

Consistent with the federal preemption doctrine, Article 9 of

*Corresponding author: Willa E Gibson, Dean's Club Professor of Law , The University of Akron School of Law, 302BuchtelCommon, Akron, OH 44325-2901, USA, Tel: 3307145877; E-mail: willa1@uakron.edu

Received March 27, 2015; Accepted April 29, 2015; Published May 11, 2015

Citation: Gibson WE (2015) The Intersection between UCC Article 9 and Intellectual Property:The Need for a National, Centralized Filing System for IP. Intel Prop Rights 3: 144. doi:10.4172/2375-4516.1000144

Copyright: () 2015 Gibson WE. This is an open-access article distributed under the terms of the Creative Commons Attribution License, which permits unrestricted use, distribution, and reproduction in any medium, provided the original author and source are credited. 
the UCC provides step-back provisions, which indicate that filing a financing statement to perfect a security interest is neither necessary nor effective if federal law preempts Article 9 perfection of such property [15]. However, the jurisprudence addressing whether federal law does preempt the UCC state perfection laws varies depending on the nature of the intellectual property. The variance stems from the differing language in the Copyright, Patent, and Lanham Acts that respectively govern copyrights, patents, and trademarks; and the variance contributes to creditor unease. To the extent that any of the federal statutes provides a national recordation scheme, the UCC state notice system is preempted because Congress intended that parties search only one single place to determine whether intellectual property interests have been transferred, thus providing notice and certainty to search parties [16]. Each of the federal statutes does contain language requiring recordation of interests to obtain priority status over competing interests; but, the priority language in each statute varies concerning the types of interests for which recordation in a federally designated office is necessary for priority purposes. In large part, creditor unease stems from not knowing whether their security interests qualify because case law analyzes the preemption question differently for each statute, and to some extent it leaves unanswered the scope of the federal statutes' preemptive power against certain types of interest.

\section{The copyright act}

The Copyright Act does provide language that courts have interpreted as preempting the UCC state perfection laws, but the Act is not a model of clarity concerning the preemption issue [17]. The Act does provide however that "any transfer of copyright ownership or other document pertaining to a copyright" may be recorded in the United States Copyright Office [17]. The Act defines a transfer to include a "mortgage [17]." Further, the Act grants priority between two conflicting transfers to the transfer executed first provided it is recorded with the Copyright Office "within month after its execution in the United States or within two months of its execution outside the United States" or before a competing transfer is recorded [18]. Courts have found that the term "transfer" in the Copyright Act includes the creation of a security interest [19]. In In re Peregrine, an oft-cited bankruptcy case holding that the Copyright Act preempts the state UCC perfection laws, the court noted that the Copyright Act's recordation system "gives nationwide, constructive notice to third parties of the recorded encumbrance [17]." The court subordinated the lender's security interest to an involuntary lien asserted by the bankruptcy trustee noting that "the Copyright Act establishes its own scheme for determining priority between conflicting transferees, one that differs in certain respects from that of Article Nine" [17]. Notwithstanding the court's finding, the Copyright Act does not explicitly define the term "transfer" to include involuntary conveyances such as a bankruptcy trustee's lien creditor rights; nonetheless, the courts have construed the term "transfer" broadly to include such conveyances [20,21]. Neither the language of the Copyright Act nor Peregrine addresses whether the Copyright Act preempts state UCC perfection laws where lenders seek to take security interests in unregistered copyrights. However, twelve years after Peregrine, the Ninth Circuit Court of Appeals in In re World Auxiliary concluded that the Copyright Act did not preempt state UCC filing requirements for perfection of unregistered copyrights since the absence of copyright registration with respect to such copyrights precluded lenders from filing any type of effective notice with the Copyright Office [22].

\section{The Lanham act}

In contrast to the Copyright Act, the Lanham Act does not specifically address security interests in trademark. The Lanham Act provides that "any assignment shall be void against any subsequent purchaser for valuable consideration without notice, unless the prescribed information reporting the assignment is recorded in the United States Patent and Trademark Office within three months after the date of the assignment prior to the subsequent purchase " [23]. The Act does not include a definition for the term "assignment. Courts have found however that the term "assignment" does not include a security interest [24]. Accordingly, court opinions have held consistently that the Lanham Act does not preempt the state UCC perfection laws [25]. In Trimarchi v. Together Development Corporation, a federal district court upheld a bankruptcy ruling [26] finding that the Lanham Act did not preempt state UCC perfection laws. The bankruptcy court reasoned that when Congress passed the Lanham Act in 1946, the term "mortgage" rather than the term "assignment" was an operative term for describing the grant of a security interest [27]. Moreover, the bankruptcy court noted that Congress intended the term "assignment" to refer to "sale of an entire business of which the trademark is a part" [27]. In affirming the bankruptcy ruling, the district court found that the "case law addressing the issue at hand consistently supports the proposition that the Lanham Act does not pertain to security interests and that Article 9, therefore, continues to govern the perfection of such interests" [28]. Notwithstanding consistent court opinions holding that the Lanham Act does not preempt the state UCC perfection laws, the United States Patent and Trademark Office (USPTO) allows and lenders' counsel typically do record their trademark security agreements with the USPTO [29].

\section{The patent act}

The Patent Act provides that "an assignment, grant, or conveyance shall be void as against a subsequent purchaser or mortgagee for a valuable consideration, without notice, unless it is recorded in the Patent and Trademark Office (PTO) within three months form its date or prior to date of such subsequent purchase or mortgage [9]." In In re Cybernetic Services, Inc., the Ninth Circuit Court of Appeals, employing the historical meaning of the terms "assignment," "grant," and "conveyance" in 1870, when the Patent Act was enacted by Congress, found that such terms meant to convey the transfer of ownership interests in patents [30]. Accordingly, the court held that the Patent Act did not preempt the state UCC perfection laws because the language of the Act spoke only to recordation in the USPTO of transfer of an ownership interest, not to the conveyance of a security interest in a patent as the term "conveyance" is understood in modern times [31]. The court noted that viewing the terms in an historical context and reading them "in light of Supreme Court precedent establishes that Congress was concerned only with providing constructive notice to subsequent parties who take an ownership interest in the patent in question [32]." Despite the unbroken line of precedent holding that the Patent Act does not preempt the state UCC filing requirements, lenders usually file a UCC-1 financing statement with the appropriate state authority and record a patent security agreement with the USPTO [32].

\section{Conclusion}

Intellectual property has become a mainstay of our economy serving as an engine for stimulating free-market enterprise. Our laws should support efficient, predictable financing mechanisms that support the collateralization of intellectual property to further enervate growth in our economy. Lender unease concerning how to perfect a security 
Citation: Gibson WE (2015) The Intersection between UCC Article 9 and Intellectual Property:The Need for a National, Centralized Filing System for IP. Intel Prop Rights 3: 144. doi:10.4172/2375-4516.1000144

interest in intellectual property stems from the absence of uniform and comprehensive jurisprudence in the area of secured financing in intellectual property. Congress should enact federal legislation establishing a national, centralized on-line filing system for recording security interests in intellectual property. Such a system would provide constructive notice to third parties and it would inject predictability into intellectual property secured financing. In the past, others have proposed recording systems to promote efficient and predictable lending in intellectual property, but Congress has failed to act $[32,33]$. As intellectual property adds trillions of dollars in value added to U.S. gross domestic product, laws governing secured financing in such property should be certain and efficient to further support economic growth.

\section{References}

1. Blank RM, Kappos DJ (2012) Intellectual Property and the U.S. Economy: Industries in Focus.

2. Tondo-Kramer K (2010) Increasing Access to Startup Financing Through Intellectual Property Securitization, $27 \mathrm{~J}$ Marshall J Computer and Info. L 27: 613-615

3. U.S. Constitution, Art. VI, cl. 2.

4. Maryland v. Louisiana, 451 U.S. 725, 746 (1981); Gibbons v. Ogden, 22 U.S. (9 Wheat) 1, 211 (1824).

5. Copyright Act, 17 U.S. C. § 205 (d).

6. Lanham Act, 15 U.S.C. $\S 1060$.

7. Patent Act 35 U.S.C $\S 261$.

8. UCC $\S \S 9-310,9-501$.

9. Security Interests: Intellectual Property, Practical Law Finance and Practical Law Intellectual Property and Technology, Resource ID 5383-5929.

10. Intellectual Property Issues-Lending, supra note 1.

11. UCC §§ 9-203; 9-308.
12. Security Interest: Intellectual Property, supra note 13.

13. UCC $\S \S 9-317,9-322$, and 9-323.

14. UCC $\S \S 9-109$ (c), 9-311 (a).

15. In re Cybernetics Services, 252 F.3d 1039 (9 $9^{\text {th }}$ Cir. 2001).

16. Copyright Act, 17 U.S.C. $\S 205$.

17. Copyright Act, 17 U.S.C. $\S 101$.

18. Copyright Act, 17 U.S.C. $\S 205$ (d).

19. In re World Auxiliary Power, 303 F.3d 1120, 1125-1126 (9 $9^{\text {th }}$ Cir. 2002);

20. In re Peregrine, 116 B.R. 194, 199 (C.D. Cal. 1990).

21. In re Franchise Pictures LLC, 389 B.R. 131, 142 (C.D. Cal. 2008).

22. In re World Auxiliary Power, 303 F.3d 1120 (9th Cir. 2002).

23. Lanham Act, 15 U.S. C. $\S 1060$ (a).

24. Trimarchi v. Together Development Corp. 255 B.R. 606 (D. Mass. 2000).

25. In the Matter of Roman Cleanser, 43 B.R. 940 (Bankr. E.D. Mich. 1984), aff'd 802 F.2d 207 (6 ${ }^{\text {th }}$ Cir. 1986); In re Chattanooga Choo-Choo Co., 98 B.R. 792 (Bankr. E.D. Tenn. 1989); In re CC. and Co., Inc., 86 B.R. 485 (Bankr. E.D. 1988); In re TR-3 Indus., 41 B.R. 128 (Bankr. C.D. Cal. 1984).

26. In re Together Development Corporation, 227 B.R. 439 (D. Mass 1998).

27. In re Together Development Corporation, 227 B.R. at 441.

28. Trimarchi, 255 B.R. at 611.

29. Intellectual Property Issues: Lending, supra note 1.

30. In re Cybernetic Serv. Inc., 252 F.3d 1039, 1048-1050 (9 $9^{\text {th }}$ Cir. 2001).

31. In re Coldwave Systems, 368 B.R. 91 (Bankr. D. Mass 2007)

32. In re Cybernetic Serv. Inc., 252 F.3d at 1054.

33. Christina Lui (2011) Navigating Through the Legal Minefield of State and Federal Filing for Perfecting Security Interests in Intellectual Property, 51 Santa Clara L. Rev 705: 729-733. 